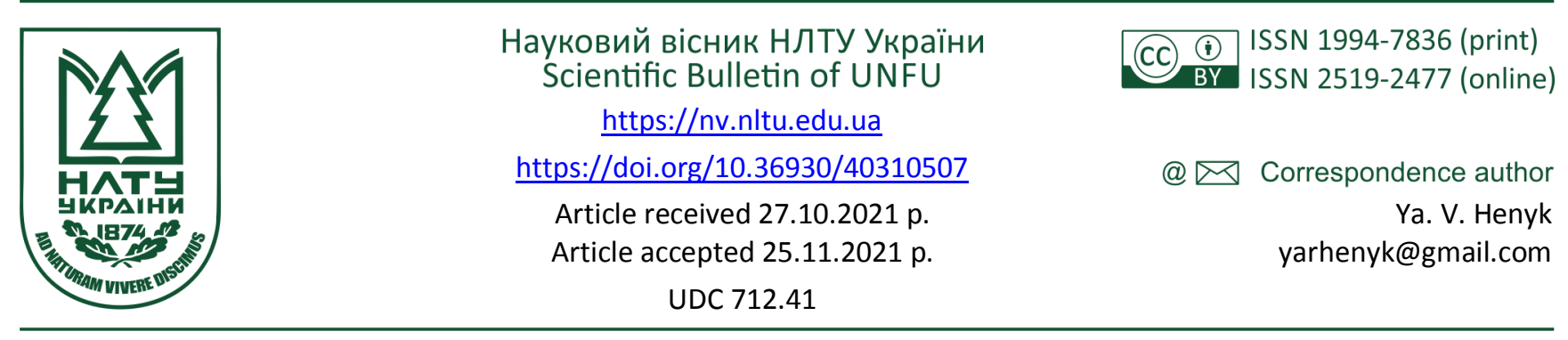

К. В. Мирончук', Я. В. Геник ${ }^{2}$

${ }^{1}$ Чернівецький національний університет ім. Ю. Федьковича, м. Чернівиі, Україна

${ }^{2}$ Національний лісотехнічний університет України, м. Львів, Украӥна

\title{
СКЛАД, ЕКОЛОГІЧНА СТРУКТУРА ТА ДЕКОРАТИВНІСТЬ ЖИВОПЛОТІВ В УРБАНІЗОВАНОМУ СЕРЕДОВИЩІ ЧЕРНІВЦІВ
}

\begin{abstract}
Наведено результати досліджень видового складу, просторової, екологічної та вікової структури живоплотів урбанізованого середовища Чернівців. Здійснено комплексне оцінювання якісного стану та декоративності живоплотів у міських зелених зонах та запропоновано заходи з покращення їх декоративності, якісного стану і функціональності. Встановлено, що для дендрофлори живоплотів Чернівців характерне незначне видове різноманіття, зокрема 17 видів деревних рослин із 13 родів та 12 родин. В озелененні міста на територіях загального користування, а також на територіях державних установ $\mathrm{i}$ підприємств переважно формують живі огорожі із самшиту вічнозеленого (Buxus sempervirens L.), пухироплідника калинолистого (Physocarpus opulifolius (L.) Мaxim.), свидини білої (Cornus alba (L.) Opiz.,), спіреї середньої (Spiraea media Schmidt.) та спіреї Вангутта (Spiraea vanhouttei Zab.). Переважна більшість живоплотів міста розміщена на територіях загального користування (48,8 \%) та сформована із одного деревного виду - 98,3\%. За екологічною структурою найчисельнішою в живоплотах відносно трофності грунтового субстрату є група мезотрофних деревних рослин - 70,5\%, а відносно вологості грунтового субстрату - група мезофітних деревних рослин - 70,6\%. За просторовою структурою серед живих огорож міста найпоширенішими є однорядні $-83,5 \%$ та середні за висотою живоплоти - 63,6 \%. Частка бордюрних живоплотів, створених переважно із спіреї середньої, самшиту вічнозеленого та барбарису Тунберга (Berberis thunbergii DC.), $\epsilon$ незначною та становить тільки $10,7 \%$. За віковою структурою в насадженнях міста найпоширенішими є 21-30-річні живоплоти - 57,9\%, а живих огорож віком понад 50 років не виявлено зовсім. Найвища оцінка декоративності у зелених зонах міста характерна для живоплотів, сформованих з барбарису Тунберга, бирючини звичайної (Ligustrum vulgare L.), садового жасмину звичайного (Philadelphus coronarius L.), сніжноягідника білого (Symphoricarpos albus (L.) Blake), спіреї середньої, спіреї Вангутта, свидини білої, свидини криваво-червоної (Cornus sanguinea (L.) Opiz.) та самшиту вічнозеленого. За якісним станом більшість живоплотів у зелених зонах Чернівців належать до категорії "добрих" - 43,0 \%, однак частка живих огорож "незадовільного" якісного стану є досить значною та становить 22,3 \%. Належне фінансування проведення необхідних агротехнічних заходів та ефективна садово-парково-господарська діяльність сприятимуть покращенню якісного стану, декоративності та естетичної привабливості живоплотів, підвищення їх стійкості до несприятливого антропогенного впливу в урбанізованому середовищі.

Ключові слова: зелена зона міста; живі огорожі; деревна рослинність; якісний стан живоплотів; міські екосистеми.
\end{abstract}

\section{Вступ / Introduction}

Урбанізаційні процеси, що супроводжуються збільшенням кількості та площ міських екосистем, зумовлюють нагальну потребу створення нових зелених насаджень у міському середовищі, які у поєднанні з уже наявними повинні формувати нові комплексні зелені зони та створювати сприятливі умови для життедіяльності живих організмів і людини. У контексті сталого розвитку урбанізованих територій, формування міських садово-паркових ландшафтів та привабливих рослинних угруповань передбачає також і вживання заходів із створення різних за функціональним призначенням і видовим складом живоплотів, які $\epsilon$ невід'ємною складовою частиною міських зелених зон і вуличних насаджень $[1$, $3,5,6,7,12,14]$.
Живоплоти, як найстаріші елементи садово-паркового будівництва, відіграють вагоме значення у захисті урбогенного середовища від негативного антропогенного впливу, а також виконують важливі природоохоронні, середовищетвірні та естетичні функції в міських екосистемах $[7,8,12]$.

Питання щодо визначення видового складу, екологічної і просторової структури живоплотів та їх життевості в урбанізованому середовищі заслуговують значної уваги та $є$ актуальними 3 огляду на потребу створення нових, стабільних і стійких зелених зон та формування оптимальної ландшафтно-просторової структури міських екосистем.

Об'єкт дослідження - живоплоти урбанізованого середовища Чернівців.

Предмет дослідження - методи і засоби встанов-

Інформація про авторів:

Мирончук Катерина Василівна, канд. с.-г. наук, асистент, кафедра ботаніки, лісового та садово-паркового господарства. Email: k.myronchuk@chnu.edu.ua; https://orcid.org/0000-0001-5462-6226

Геник Ярослав Вячеславович, д-р с.-г. наук, доцент, завідувач кафедри ландшафтної архітектури, садово-паркового господарства та урбоекологіï. Email: yarhenyk@gmail.com; https://orcid.org/0000-0002-6079-6827

Цитування за Дсту: Мирончук К. В., Геник Я. В. Склад, екологічна структура та декоративність живоплотів в урбанізованому середовищі Чернівців. Науковий вісник НЛТУ України. 2021, т. 31, № 5. С. 47-53.

Citation APA: Myronchuk, K. V., \& Henyk, Ya. V. (2021). Composition, ecological structure and ornamental value of hedges in the urbanized environment in Chernivtsi. Scientific Bulletin of UNFU, 31(5), 47-53. https://doi.org/10.36930/40310507 
лення видового складу, екологічної, просторової та вікової структури, декоративність та якісний стан живоплотів міської екосистеми Чернівців.

Мета роботи - проаналізувати рослинні угруповання, екологічну, просторову та вікову структуру, декоративності та якісного стану живоплотів у зелених зонах міста Чернівців.

Для досягнення зазначеної мети визначено такі основні завдання дослідження: встановити видовий склад, структуру рослинності; оцінити декоративність та якісний стан живоплотів урбанізованого середовища Чернівців. Унаслідок проведення досліджень здійснено інвентаризацію та обліковано деревні рослини 121 живоплоту в зелених зонах міста.

Наукова новизна отриманих результатів дослідження - вперше проаналізовано дендрофлору живоплотів урбанізованого середовища Чернівців; визначено видовий склад живих огорож та встановлено особливості їх екологічної, просторової та вікової структури в міській екосистемі; здійснено комплексне оцінювання якісного стану і декоративності живоплотів у міських зелених зонах; запропоновано заходи із покращення їх декоративності, якісного стану та функціональності.

Практична значущиість отриманих результатів дослідження - їх доцільно використати з метою: підбору асортименту деревних рослин для формування багатих за видовою різноманітністю та складних за структурою живоплотів; розроблення заходів із покращення екологічної та вікової структури та функціональності живих огорож у міських екосистемах; підвищення якісного стану та декоративності садово-паркових ландшафтів; удосконалення процесу формування нових живоплотів в урбанізованому середовищі; розроблення архітектурно-ландшафтних моделей створення різних за функціональним призначенням живоплотів в урбанізованих екосистемах.

Аналіз останніх досліджень та публікацій. Вагоме значення у вивченні процесів функціонування міських екосистем відводять питанням формування естетично привабливих зелених насаджень, важливим компонентом яких $\epsilon$ і живі огорожі - живоплоти. Створення нових та реконструкція наявних зелених насаджень у міському середовищі $є$ неможливими без формування різних за функціональним призначенням, просторовою структурою і видовим складом живоплотів.

Результати досліджень біоекологічної структури, видового складу та життєвості живоплотів в урбанізованому середовищі висвітлено у численних напрацюваннях як закордонних, так і вітчизняних науковців: Forman, L. Hannon, N. Mpandeli, P. Muras, А. Сапелин, В. Кучерявий $[3,4,7,9,10]$.

Наукові дослідження щодо встановлення структури та якісного стану рослинних угруповань в урбанізованому середовищі доводять значний ландшафтний потенціал живих огорож. Важлива роль живоплотів проявляється також і в розв'язанні екологічних проблем міського середовища та виконання ними різноманітних екологічних, середовищетвірних, захисних, фітонцидних, естетичних і рекреаційно-оздоровчих функцій [3, $4,7,8,9,10,12]$.

Живоплоти в урбанізованих екосистемах, як інша деревна і трав'яна рослинність, зазнають істотного негативного антропогенного впливу, що проявляється на- самперед у механічному пошкодженні рослин і порушенні просторової структури рослинних угруповань. Недотримання технологій створення, недостатність потрібних агротехнічних заходів та несвоєчасність проведення доглядів за живоплотами призводять сукупно до негативних змін у їх біоекологічній структурі та видовому складі, а також спричиняє зниження життєвості рослин і їх стійкості до несприятливих природних і антропогенних чинників урбанізованого середовища $[7,8,12]$.

Дослідження питань життєвості рослинних угруповань в урбанізованому середовищі, показали зміни в морфологічній будові, екологічній структурі, якісному стані, рості та розвитку різних рослин у живоплотах міських екосистем [8, 11, 12].

Незважаючи на вагомість наукових напрацювань щодо створення та формування живоплотів у міському середовищі, питання встановлення видового складу, екологічної та просторової структури живих огорож, підвищення їх декоративної привабливості та стійкості до несприятливих антропогенних чинників і надалі $€$ актуальними, що потребує нових грунтовних наукових досліджень.

Встановлення особливостей стану, складу, структури та декоративності живоплотів у зелених насадженнях урбанізованих екосистем, зокрема і в міській екосистемі Чернівців, сприятиме процесам формування естетично привабливих і декоративних, стійких і стабільних рослинних угруповань живих огорож у міському середовищі.

Матеріали та методи дослідження. Дослідження проведено зважаючи на поставлені завдання щодо вивчення питань із встановлення видового складу та структури рослинних угруповань живоплотів, визначення їх якісного стану, декоративності та функціональності у зелених зонах урбанізованих екосистем. Під час виконання досліджень застосовано загальнонаукові, картографічні, флористичні, порівняльні та математично-статистичні методи.

Дослідження здійснено за апробованими методиками, відповідно до завдань системного підходу до аналізу рослинності живоплотів, їх структури, якісного стану та декоративності.

Інвентаризацію живих огород у зелених зонах Чернівців здійснено на основі картографічних матеріалів маршрутним методом, відповідно до вимог "Інструкції 3 технічної інвентаризації зелених насаджень ..." [13]. Видовий склад рослинних угруповань живоплотів встановлено відповідно до вітчизняної номенклатури назв $[2,15]$. Екологічну структуру живих огорож урбанізованого середовища визначено відповідно до "Определитель растений..." [2]. За висотою живоплоти класифіковано на бордюрні (висота до 0,5 м), низькі (0,5-1,0 м), середні (1,0-2,0 м) та високі (понад 2 м). Бальне оцінювання декоративності живих огорож виконували за модифікованою шкалою оцінки декоративності ознак кущів $[11,12]$. Якісний стан живоплотів класифіковано на "добрий", "задовільний" та "незадовільний".

Загалом дослідженнями охоплено деревні рослинні угруповання 121 живоплоту в зелених зонах Чернівців, які репрезентативно представляють насадження урбанізованого середовища та відображають процеси, що відбуваються у зелених міських екосистемах. 


\section{Результати дослідження та їх обговорення / Research results and their discussion}

Живоплоти у зелених зонах Чернівців, як елементи озеленення міста, охоплюють невеликі площі та розташовані зазвичай уздовж магістральних вулиць, на площах та серед житлової забудови. Створення і формування живоплотів, як елементу садово-паркового мистецтва та процесу озеленення Чернівців, відбулось внаслідок впливу різних природних і антропогенних чинників, серед яких основними були:

- перспективні плани та соціально-економічні умови розвитку міста;

- наявність зелених зон та їх розташування;

- нормативна площа зелених насаджень у міській забудові та перспективність і потребу формування живих огорож;

- щорічні обсяги фінансування заходів із створення та формування зелених насаджень міста, зокрема і живоплотів;

- здійснення необхідних агротехнічних заходів та своєчасність догляду за зеленими насадженнями в міській екосистемі.

Проведення інвентаризації живоплотів та здійснення досліджень щодо складу і структури рослинних угруповань живих огорож у зелених зонах Чернівців упродовж 2010-2020 pр., показали їх поширеність та активне використання для формування міських зелених насаджень, а також різноманітність їх видового складу, екологічної структури та функціонального призначення.

Переважна частина живоплотів міста сформована на територіях обмеженого користування (43,8 \% від кількості обстежених живих огорож), а найменше їх сформовано на територіях загального користування - 20,3\% (рис. 1). Основним функціональним призначенням живоплотів у міській забудові Чернівців є: розмежування та озеленення територій, покращення естетичного вигляду та декоративності зелених зон.

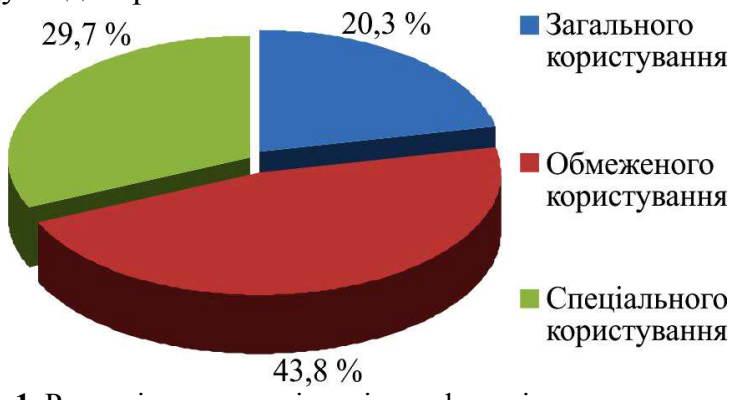

Рис. 1. Розподіл живоплотів у різних функціональних зонах Чернівців / The distribution of hedges in different functional areas in Chernivtsi's green spaces

Дендрофлора живоплотів урбанізованого середовища Чернівців характеризується відносно багатим біорізноманіттям та представлена 17 видами деревних рослин iз 13 родів та 12 родин (табл. 1). У таксономічному складі деревних рослин живоплотів за кількістю видів провідними є родини Rosaceae Juss. - 3 види та Oleaceae Lindl. - 2 види. Решта родин має тільки один деревний вид.

Табл. 1. Систематичний склад дендрофлори живоплотів зелених зон Чернівців / Systematic composition of hedge dendroflora in Chernivtsi's green spaces

\begin{tabular}{|c|c|c|c|c|c|}
\hline \multirow{2}{*}{ Відділ } & \multirow{2}{*}{ Клас } & \multicolumn{5}{|c|}{ Кількість } \\
\cline { 3 - 6 } & & рядів & родин & родів & видів \\
\hline \multicolumn{5}{|c|}{ м. Черівці } \\
\hline Pinophyta & Pinopsida & 1 & 2 & 2 & 2 \\
\hline Magnoliophyta & Magnoliopsida & 9 & 10 & 11 & 15 \\
\hline \multicolumn{2}{|c|}{ Загалом } & 10 & 12 & 13 & 17 \\
\hline
\end{tabular}

Біологічне різноманіття деревних рослин живоплотів залежить насамперед від його функціонального призначення та вартості садивного матеріалу, який використовують для формування живих огорож. В озелененні міста на територіях загального користування, а також на територіях державних установ і підприємств переважно формують живі огорожі із самшиту вічнозеленого (Buxus sempervirens L.), пухироплідника калинолистого (Physocarpus opulifolius (L.) Maxim.), свидини білої (Cornus alba (L.) Opiz.), спіреї середньої (Spiraea media Schmidt.) та спіреї Вангутта (Spiraea vanhouttei Zab.) Рідше для формування живоплотів використовують сніжноягідник білий (Symphoricarpos albus (L.) Blake), свидину криваво-червону (Cornus sanguinea (L.) Opiz.), тую західну (Thuja occidentalis L.) та ялину звичайну (Picea abies Karst.) (табл. 2).

Табл. 2. Видовий склад та кількість живоплатів у зелених зонах Чернівців / Species compositionand the number of hedges in Chernivtsi's green spaces

\begin{tabular}{|c|c|c|c|}
\hline \multirow{2}{*}{$\begin{array}{l}\text { № } \\
\text { 3/П }\end{array}$} & \multirow{2}{*}{ Назва виду } & \multicolumn{2}{|c|}{ Кількість, } \\
\hline & & ШТ. & $\%$ \\
\hline 1 & Барбарис Тунберга (Berberis thunbergii DC.) & 1 & 0,8 \\
\hline 2 & Бирючина звичайна (Ligustrum vulgare L.) & 10 & 8,3 \\
\hline 3 & Граб звичайний (Carpinus betulus L.) & 4 & 3,3 \\
\hline 4 & $\begin{array}{l}\text { Дівочий виноград п'ятилисточковий (Partheno- } \\
\text { cissus quinquefolia Planch.) }\end{array}$ & 8 & 6,6 \\
\hline 5 & Жимолость Генрі (Lonicera henryi L.) & 2 & 1,7 \\
\hline 6 & Липа дрібнолиста (Tilia cordata Mill.) & 1 & 0,8 \\
\hline 7 & $\begin{array}{l}\text { Пухироплідник калинолистий (Physocarpus opu- } \\
\text { lifolius (L.) Maxim.) }\end{array}$ & 15 & 12,4 \\
\hline 8 & $\begin{array}{l}\text { Садовий жасмин звичайний (Philadelphus coro- } \\
\text { narius L.) }\end{array}$ & 1 & 0,8 \\
\hline 9 & Самшит вічнозелений (Buxus sempervirens L.) & 27 & 22,3 \\
\hline 10 & Свидина біла (Cornus alba (L.) & 21 & 17,4 \\
\hline 11 & $\begin{array}{l}\text { Свидина криваво-червона (Cornus sanguinea (L.) } \\
\text { Opiz.) }\end{array}$ & 3 & 2,5 \\
\hline 12 & $\begin{array}{l}\text { Сніжноягідник білий (Symphoricarpos albus (L.) } \\
\text { Blake), }\end{array}$ & 4 & 3,3 \\
\hline 13 & Спірея Вангутта (Spiraea vanhouttei Zab.) & 8 & 6,6 \\
\hline 14 & Спірея середня (Spiraea media Schmidt.) & 10 & 8,3 \\
\hline 15 & Туя західна (Thuja occidentalis L.) & 2 & 1,7 \\
\hline 16 & Форзиція повисла (Forsythia suspense Vahl.) & 2 & 1,7 \\
\hline 17 & Ялина звичайна (Picea abies Karst.) & 2 & 1,7 \\
\hline & Всього & 121 & 100 \\
\hline
\end{tabular}

За результатами аналізу видового складу деревних рослин у живоплотах міста з'ясовано, що найчастіше для створення живих огорож використовують: самшит вічнозелений $(22,3 \%)$, свидину білу $(17,4 \%)$, пухироплідник калинолистий $(12,4 \%)$, бирючину звичайну $(\mathrm{Li}$ gustrum vulgare L.) (8,3\%) та спірею середню (8,3\%). Не так часто для формування живих огорож використовують жимолость Генрі (Lonicera henryi L.), тую західну, форзицію повислу (Forsythia suspense Vahl.) та ялину звичайну. Поодиноко в зелених зонах міста формують живоплоти з барбарису Тунберга (Berberis thunbergii DC.), липи дрібнолистої (Tilia cordata Mill.) та садового жасмину звичайного (Philadelphus coronarius L.).

Переважна більшість живоплотів у Чернівцях сформована із одного деревного виду (чисті живоплоти) 98,3\%. Частка змішаних живоплотів у зелених зонах міста (створені із двох і більше деревних видів) є досить незначною та становить тільки 1,7 \%. Інколи у живоплотах міста трапляються нехарактерні для їх формування деревні види, зокрема липи дрібнолистої. 
Аналіз особливостей екологічної структури живоплотів, що дає змогу з'ясувати залежність деревних рослин від родючості та вологості грунтового покриву, показав, що відносно трофності грунтового субстрату найпоширенішою $є$ група мезотрофних деревних рослин $-70,5 \%$. Значну частку живоплотів міста також формують і вибагливі до грунтових умов деревні рослини мегатрофи $-17,7$ \%. Натомість частка оліготрофних деревних видів, які $\epsilon$ невибагливими до грунтових умов, є незначною - тільки $11,8 \%$ (рис. 2).

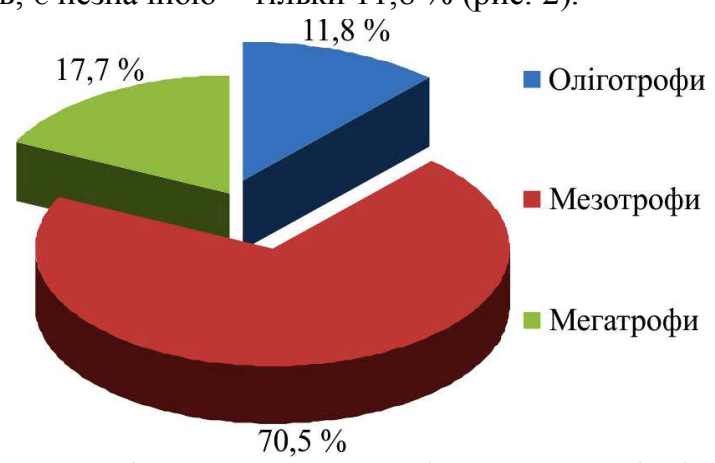

Рис. 2. Екологічна структура дендрофлори живоплотів відносно трофності грунтового субстрату / Ecological structure of hedge dendroflora regarding the trophism of the soil substrate

Відносно вологості грунтового субстрату найчисельнішими у живоплотах міста $є$ мезофітні деревні рослини $-70,6 \%$. Частка мезоксерофітних деревних рослин у живоплотах міста $\epsilon$ незначною та становить тільки 5,9\%, а гігрофітні та гідрофітні деревні рослини в живих огорожах міста зовсім відсутні (рис. 3).

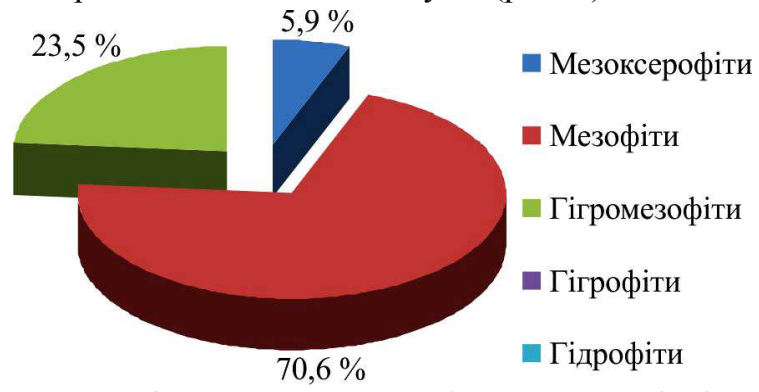

Рис. 3. Екологічна структура дендрофлори живоплотів відносно вологості грунтового субстрату / Ecological structure of hedge dendroflora regarding the humidity of the soil substrate

У зелених зонах Чернівців переважно трапляються формовані живоплоти, частка яких становить 79,3%. У видовому складі формованих живоплотів переважають самшит вічнозелений, свидина біла, спірея середня, бирючина звичайна. Частка неформованих живоплотів $\epsilon$ незначною (20,7 \%), а у їх видовому різноманітті переважають живоплоти, сформовані із свидини кривавочервоної, спіреї Вагутта та сніжноягідника білого. Внаслідок неналежного агротехнічного догляду, деякі формовані живоплоти перейшли в категорію не формованих, зокрема живоплоти, створені із граба звичайного (Carpinus betulus L.), пухироплідника калинолистого та ялини звичайної.

Серед живих огорож міста найпоширенішими є однорядні живоплоти, частка яких є досить значною $83,5 \%$.Частка багаторядних живоплотів $є$ незначною $16,5 \%$, серед яких 14,0 \% дворядних та 2,5\% трирядних живих огорож (рис. 4). Невелику кількість багаторядних живоплотів у Чернівцях насамперед пояснюють щільною забудовою міста та нестачею необхідного простору для їх формування.

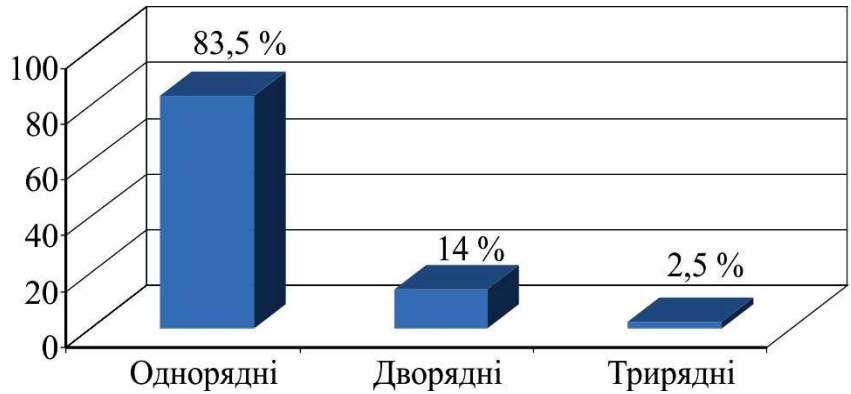

Рис. 4. Рядність живоплотів у зелених зонах Чернівців / Hedges row in Chernivtsi's green spaces

Аналізуючи вертикальну структуру живоплотів зелених зон Чернівців, з'ясували, що за висотою у місті переважають середні живоплоти - 63,6 \%, що насамперед пов'язано із великою кількістю живих огорож, створених із пухироплідника калинолистого, свидини білої та сніжноягідника білого. Частка бордюрних живоплотів, переважно створених із спіреї середньої, самшиту вічнозеленого та барбарису Тунберга, є незначною та становить тільки $10,7 \%$ (рис. 5).

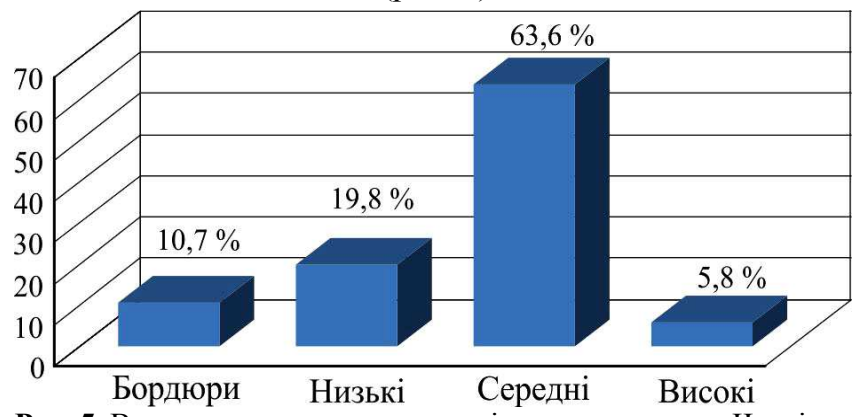

Рис. 5. Висотна структура живоплотів у зелених зонах Чернівців / Hedge height structure in Chernivtsi's green spaces

За результатами аналізу вікової структури живоплотів у зелених зонах встановлено, що в місті найпоширенішими є 21-30-річні живі огорожі, частка яких становить 57,9\%. Значна частка живоплотів міста має вік 1120 років $-20,7 \%$. У зелених зонах Чернівців не трапляються живоплоти у віці понад 50 років (рис. 6).

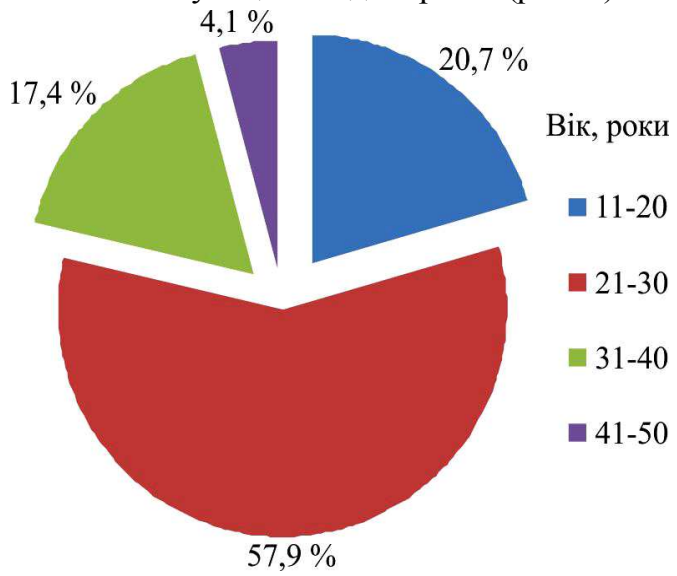

Рис. 6. Вікова структура живоплотів у зелених зонах Чернівців

/ Hedge age structure in Chernivtsi's green spaces

Оцінювання декоративності чистих і мішаних живоплотів міста показало, що для кожної деревної рослини характерні свої індивідуальні властивості та параметри, які безпосередньо впливають на декоративність живої огорожі. Оцінювання декоративності деревних рослин у живоплоті за такими показниками, як щільність крони, колір пагонів, форма і колір листя, термін і тривалість цвітіння, розмір і колір плодів та аромат да- 
ло змогу визначити декоративність сформованих живих огорож. Загалом найвища оцінка декоративності у зелених зонах міста (понад 30 балів) характерна для живоплотів, сформованих з барбарису Тунберга, бирючини звичайної, жимолості Генрі, самшиту вічнозеленого, свидини криваво-червоної, сніжноягідника білого та ялини звичайної (табл. 3).

Табл. 3. Декоративність живоплотів за оптимальних умов зростання у зелених зонах Чернівців / Hedge ornamental value under optimal growth conditions in Chernivtsi's green spaces

\begin{tabular}{|c|c|c|c|c|c|c|c|c|}
\hline $\begin{array}{l}\text { № } \\
\text { 3/ח }\end{array}$ & Назва виду & Крона & Пагони & Листки & Цвітіння & Плоди & Аромат & $\begin{array}{c}\text { Загалом деко- } \\
\text { ративність }\end{array}$ \\
\hline 1 & Барбарис Тунберга & 6 & 3 & 13 & 3 & 7 & 1 & 33 \\
\hline 2 & Бирючина звичайна & 6 & 1 & 10 & 6 & 5 & 2 & 30 \\
\hline 3 & Граб звичайний & 3 & 1 & 9 & 0 & 6 & 1 & 20 \\
\hline 4 & Дівочий виноград п'ятилисточковий & 6 & 3 & 8 & 3 & 6 & 1 & 27 \\
\hline 5 & Жимолость Генрі & 3 & 3 & 14 & 6 & 6 & 1 & 33 \\
\hline 6 & Липа дрібнолиста & 6 & 3 & 8 & 5 & 4 & 2 & 28 \\
\hline 7 & Пухироплідник калинолистий & 3 & 1 & 8 & 7 & 7 & 1 & 27 \\
\hline 8 & Садовий жасмин звичайний & 6 & 1 & 8 & 6 & 6 & 2 & 29 \\
\hline 9 & Самшит вічнозелений & 6 & 1 & 15 & 2 & 5 & 3 & 32 \\
\hline 10 & Свидина біла & 3 & 3 & 8 & 6 & 7 & 1 & 28 \\
\hline 11 & Свидина криваво-червона & 6 & 3 & 8 & 6 & 6 & 1 & 30 \\
\hline 12 & Сніжноягідник білий & 6 & 1 & 7 & 6 & 7 & 2 & 31 \\
\hline 13 & Спірея Вангутта & 6 & 1 & 8 & 6 & 6 & 2 & 29 \\
\hline 14 & Спірея середня & 6 & 1 & 10 & 7 & 3 & 1 & 28 \\
\hline 15 & Туя західна & 6 & 1 & 11 & 1 & 5 & 2 & 26 \\
\hline 16 & Форзиція повисла & 3 & 1 & 9 & 6 & 3 & 0 & 22 \\
\hline 17 & Ялина звичайна & 6 & 1 & 15 & 4 & 8 & 2 & 33 \\
\hline
\end{tabular}

Можна виокремити живоплоти, сформовані із самшиту вічнозеленого, які не втрачають своєї декоративності впродовж усього року, а під час цвітіння виділяють приємний аромат. Досить оригінально та цікаво виглядають живоплоти, сформовані із свидини білої та свидини криваво-червоної. Досить ефектними та привабливими є живоплоти, сформовані із бирючини звичайної та сніжноягідника білого.

Проведені дослідження показали, що за якісним станом більшість живоплотів у зелених зонах Чернівців можна віднести до категорії "добрих" - 43,0 \% (рис. 7). Частка живих огорож "незадовільного" якісного стану становить $22,3 \%$, що вказує на потребу здійснення заходів із часткової чи повної їх реконструкції, або ж виконання агротехнічних і доглядових робіт. Живоплоти "незадовільного" якісного стану мають сухе листя та гілки, зріджені деревні крони, механічні пошкодження деревної рослинності.

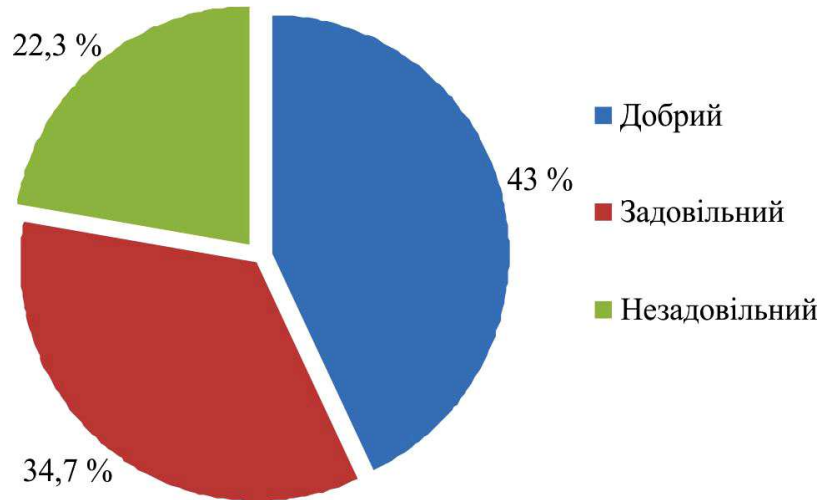

Рис. 7. Якісний стан живоплотів у зелених зонах Чернівців / Hedge quality in Chernivtsi's green spaces

Якісний стан живоплотів міста безпосередньо залежить від інтенсивності освітлення деревної рослинності. Частка живоплотів "незадовільного" якісного стану, деревні рослини яких отримують достатньо освітлення, $\epsilon$ значно меншою $(13,5 \%)$, порівняно із часткою живоп- лотів, які ростуть у напівтіні $(26,7 \%)$ та в тіні $(55,6 \%)$ (табл. 4)

Табл. 4. Якісний стан живоплотів Чернівців залежно від рівня освітленості / Hedge quality in Chernivtsi depending on the level of lighting

\begin{tabular}{|c|c|c|c|c|c|c|}
\hline \multirow{2}{*}{$\begin{array}{c}\text { Якісний } \\
\text { стан жи- } \\
\text { воплотів }\end{array}$} & $\begin{array}{c}|c| \\
\text { кіль- } \\
\text { кість, } \\
\text { шт. }\end{array}$ & $\begin{array}{c}\% \text { жах ме- } \\
\text { пи- }\end{array}$ & $\begin{array}{c}\text { кіль- } \\
\text { кість, } \\
\text { шт. }\end{array}$ & $\begin{array}{c}\% \text { жах ме- } \\
\text { пру- } \\
\text { пи }\end{array}$ & $\begin{array}{c}\text { кіль- } \\
\text { кість, } \\
\text { шт. }\end{array}$ & $\begin{array}{c}\% \text { у ме- } \\
\text { жах гру- } \\
\text { пи }\end{array}$ \\
\hline Добрий & 32 & 61,5 & 19 & 31,7 & 1 & 11,1 \\
\hline $\begin{array}{c}\text { Задовіль- } \\
\text { ний }\end{array}$ & 13 & 25 & 25 & 41,7 & 3 & 33,3 \\
\hline $\begin{array}{c}\text { Незадо- } \\
\text { вільний }\end{array}$ & 7 & 13,5 & 16 & 26,7 & 5 & 55,6 \\
\hline Всього & 52 & 100 & 60 & 100 & 9 & 100 \\
\hline
\end{tabular}

Загалом основними причинами "незадовільного" якісного стану живоплотів міста є:

- невідповідність агротехніки їх створення;

- недотримання календарного плану їх догляду та формування;

- неправильне обрізування гілок;

- несвоєчасність здійснення заходів із захисту від фітохвороб і ентомошкідників;

- недостатнє фінансування заходів із догляду за насадженнями міських зелених зон.

Неналежне фінансування на здійснення заходів із догляду та неефективна садово-парково-господарська діяльність призводять до погіршення якісного, естетичного та санітарного стану живоплотів, зниження їх біологічної стійкості до несприятливих антропогенних чинників.

Для покращення декоративності, якісного стану та функціональності живоплотів необхідно здійснювати низку агротехнічних заходів, насамперед таких, як мульчування, підживлення, поливання, профілактику проти пошкоджень ентомошкідниками і фітохворобами, обрізування крони та формування просторової структури. Важливими заходами також $є$ i введення у структуру живоплотів нових декоративних деревних 
видів, збільшення і комбінування рядності та формування змішаних багатовидових живих огорож.

Розроблення наукових засад створення і формування живоплотів, застосування новітніх технологій і своєчасне проведення заходів із догляду за ними сприятиме процесам відновлення естетично привабливих і декоративних елементів садово-паркового мистецтва в урбанізованих ландшафтах.

\section{Висновок / Conclusions}

Велика кількість і протяжність живоплотів у зелених зонах урбанізованого середовища Чернівців, а також відносно багате їх видове різноманіття, складна структура, висока декоративність та задовільний якісний стан свідчать про широке застосування живих огорож в озелененні міста.

Живоплоти, як компонент озеленення урбанізованого середовища Чернівців, переважно сформовані на територіях обмеженого користування $(43,8 \%)$ та на територіях спеціального користування - 29,7 \%.

Дендрофлора живоплотів міста характеризується відносно багатим біорізноманіттям та сформована 17 видами деревних рослин із 13 родів та 12 родин. У таксономічному складі дендрофлори живих огорож провідними є родини Rosaceae Juss. та Oleaceae Lindl.

Для створення живоплотів у зелених зонах міста найчастіше використовують самшит вічнозелений $(22,3 \%)$, свидину білу $(17,4$ \%) та пухироплідник калинолистий $(12,4 \%)$. Переважна більшість живих огорож сформована із одного деревного виду $-98,3 \%$.

За екологічною структурою найчисельнішою в живоплотах відносно трофності грунтового субстрату $є$ група мезотрофних деревних рослин - 70,5 \%, а відносно вологості грунтового субстрату - група мезофітних деревних рослин $-70,6 \%$.

У зелених зонах Чернівців переважають однорядні живоплоти $-83,8 \%$, а частка трирядних живих огорож становить тільки 2,5 \%. У видовому складі формованих живоплотів (79,3\%) переважають самшит вічнозелений, свидина біла, спірея середня, бирючина звичайна.

За висотою у місті домінують середні (1,0-2,0 м) живоплоти - 63,6 \%, які переважно сформовані із пухироплідника калинолистого, свидини білої та сніжноягідника білого. Частка бордюрних живоплотів, сформованих переважно із спіреї середньої, самшиту вічнозеленого та барбарису Тунберга, становить $10,7 \%$.

За віковою структурою найпоширенішими живоплотами у Чернівцях є 11-20-річні (20,7 \%) та 21-30-річні $(57,9 \%)$ живі огорожі. Живоплотів віком понад 50 років у зелених зонах міста не виявлено.

Найвищу оцінку декоративності у зелених зонах міста мають живоплоти, сформовані з барбарису Тунберга, бирючини звичайної, жимолості Генрі, самшиту вічнозеленого, свидини криваво-червоної, сніжноягідника білого та ялини звичайної.

За якісним станом більшість живоплотів у зелених зонах Чернівців належить до категорії "добрих" 43,0 \%. Однак частка живих огорож "незадовільного" якісного стану є досить високою та становить 22,3\%. Частка живоплотів у "незадовільному" стані, які отримують достатньо освітлення, є значно меншою (13,5 \%) порівняно із часткою живоплотів, які ростуть у тіні $(55,6 \%)$
Невідповідність агротехніки створення, неправильне формування, а також неналежне фінансування на здійснення заходів із захисту та догляду за живоплотами призводять до погіршення якісного стану та естетичної привабливості живих огорож, зниження їх біологічної стійкості до несприятливих антропогенних чинників в урбанізованому середовищі.

Здійснений аналіз видового складу, екологічної та просторової структури живоплотів, їх декоративності та якісного стану сприятиме надалі проведенню ефективних заходів та робіт із формування багатих за видовим складом і складних за структурою живих огорож різного цільового призначення в урбанізованих екосистемах країни.

\section{References}

1. Bilous, V. I. (2001). Sadovo-parkove mystetstvo. Korotka istoriia rozvytku ta metody stvorennia khudozhnikh sadiv. Kyiv: Naukovyisvit, 299 p. [In Ukrainian].

2. Dobrochaeva, D. N., Kotov, M. I., \& Prokudin, Yu. N. (1999). Opredelitel vyisshih rasteniy Ukrainy. Kiev: Fitosotsiotsentr, 548 p. [In Russian].

3. Forman, R. T. T., \& Baudry, J. (1984). Hedgerowsandhedgerownet worksinlandscape ecology. Environmental Management, Vol. 8, 499-510. https://ui.adsabs.harvard.edu/abs/1984EnMan...8.495F/abstract

4. Hannon, L. E., \& Sisk, T. D. (2009). Hedgerowsinanagri-naturall and scape: Potential habitat valuefornative bees. Biological Conservation, Vol. 142, 2140-2154. https://ur.booksc.org/book/16602577/7de94 c

5. Henyk, Ya. V., Dudyn, R. B., Dyda, A. P., Marutyak, S. B., \& Kaspruk, O. I. (2017). Transformatsiyni protsesy v lisoparkovykh i parkovykh nasadzhennyakh urbanizovanykh ekosystem Zakhodu Ukrayiny. Scientific Bulletin of UNFU, 27(10), 9-15. https://doi.org/10.15421/40271001

6. Kucheriavyi, V. P. (2018). Istoriialandshaftnoiarkhitektury. Lviv: Novyi-Svit-2000, 762 p. [In Ukrainian].

7. Kucheriavyi, V. P. (2019). Landscaping of settlements. Lviv: Novyysvit, 620 p. [In Ukrainian].

8. Kurnytska, M. P., Myronchuk, K. V. (2011). Stanzhyvoplotiv u suchasnomumisti. ScientificBulletinof UNFU, 21(3), 8-11. [In Ukrainian].

9. Mpandeli, N. S. (2005). Two-dimennal soil water evaporation in hedgerow orchards: Presented in partial fulfillment of the requirements for the degree m. Inst. Agrar. (Agronomy). The faculty of natural and agricultural sciences department of plant production and soil science University of Pretoria. Pretoria, UP. 47 p. Retrieved from: https://repository.up.ac.za/bitstream/handle/2263/29393/dissertation.pdf? sequence=1\&isAllowed $=y$

10. Muras, P., \& Frazik-Adamczyk Żywoploty, M. (2002). Wyd. Plantpress. Kraków, 111 p. Retrieved from: https://journals.pan.pl/Content/94393/mainfile.pdf

11. Myronchuk, K. V. (2017). Metodyka otsiniuvannia dekoratyvnykh vlastyvostei. ScientificBulletinof UNFU, 27(3), 57-61. https://doi.org/10.15421/40270312

12. Myronchuk, K. V. (2018). ZhyvoplotyBukovyny: monohrafiia. Chernivtsi: Chernivetskyi Natsionalnyi universytetim. Yu. Fedkovycha. 256 p. [In Ukrainian].

13. Nakaz. (2001). Instruktsiia ztekhnichnoi inventaryzatsii zelenykh nasadzhen u mistakh taselyshchakh miskoho typu Ukrainy (Nakaz Derzhkomitetubudivnytstva, arkhitektury ta zhytlovoi polityky Ukrainy, № 226 vid 24.12.2001). [In Ukrainian].

14. Sapelin, A. Yu. (2008). Zhivyie izgorodi. Moscow: Kladez Buks, 124 p. [In Russian].

15. Zaiachuk, V. Ya. (2014). Dendrolohiia. Lviv: Spolom, 676 p. [In Ukrainian]. 


\section{COMPOSITION, ECOLOGICAL STRUCTURE AND ORNAMENTAL VALUE OF HEDGES IN THE URBANIZED ENVIRONMENT IN CHERNIVTSI}

The issues of determining the species composition, ecological and spatial structure of hedges and their vitality in the urban environment deserve considerable attention in the context of sustainable development of urban areas. Therefore, these issues are relevant considering the need to create new, steady and sustainable green spaces and the formation of optimal landscape-spatial structure of urban ecosystems. The purpose of the research is to define the species composition, ecological, spatial and age structure, ornamental value and quality of hedges in green spaces of the urban environment of Chernivtsi. The study was carried out according to proven methods, in accordance with the objectives of a systematic approach to the analysis of hedge vegetation, their structure, quality and decoration. The conducted research has revealed that the dendroflora of hedges in Chernivtsi is characterized by insignificant species diversity, in particular 17 species of woody plants from 13 genera and 12 families. The landscaping of the city in public areas, as well as in public institutions and enterprises is mainly formed by hedges composed of boxwood evergreen (Buxus sempervirens L.), Eastern ninebark (Physocarpus opulifolius (L.) Maxim.), Siberian dogwood (Cornus alba (L.) Opiz.,), sriraea medium Schmidt. (Sriraea media Schmidt.), and spiraea Vanhouttei (Spiraea vanhouttei Zab.). The vast majority of the citys hedges are located in public areas $(48.8 \%)$ and are formed from one tree species $-98.3 \%$. Ecological structure is presented by the group of mesotrophic woody plants which are the most numerous in hedges in terms of soil substrate trophism $-70.5 \%$, and soil substrate moisture is characterized by the group of mesophytic woody plants $-70.6 \%$. In terms of spatial structure, the most common hedges in the city are single-row $83.5 \%$ and medium-height hedges $-63.6 \%$. The share of border hedges, composed mainly from spirea medium, boxwood evergreen and the Japanese barberry (Berberis thunbergii DC.), is insignificant and equils only $10.7 \%$. According to the age structure, the most common plantations in the city are 21-30-year-old hedges $-57.9 \%$, and hedges over 50 years old have not been detected at all. The highest assessment of ornamental value in the citys green spaces is characterized by hedges composed from the Japanese barberry, European privet (Ligustrum vulgare L.), mosk orange (Philadelphus coronarius L.), common snowberry (Symphoricarpos albus (L.) Blake), spirea Vanhouttei spirea medium, Siberian dogwood, bloody dogwood (Cornus sanguinea (L.) Opiz.) and evergreen boxwood. Considering quality, most hedges in Chernivtsis green spaces belong to the category of "good" constituting $43.0 \%$, but the share of hedges of "unsatisfactory" quality is quite significant and is $22.3 \%$. Adequate funding for the necessary agro-technical measures and effective garden and park activities will help improve the quality, decorative and aesthetic appeal of hedges, increase their resilience to adverse anthropogenic impacts in the urban environment.

Keywords: urban green space; hedges; tree vegetation; quality of hedges; urban ecosystems. 